\title{
ACCOUNTABILITY AND TRANSPARENCY IN NATION BUILDING: A COVID-19 EXPERIENCE IN SUB-SAHARAN AFRICA
}

\author{
Ojiagu, Nkechi \\ Cordelia $^{1}$ \\ (iD) Nzewi, Hope \\ $\mathrm{Ngozi}^{2}$ \\ Arachie, Augustine \\ Ebuka $^{3+}$
}

\author{
'Department of Cooperative Economics and Management, Nnamdi Azikiwe \\ University, Awka Nigeria. \\ ${ }^{2}$ Email:nc.ojiagu@unizik.edu.ng.Tel:+2348032625656 \\ ${ }^{2, s}$ Department of Business Administration, Nnamdi Azikiwe University, \\ Awka Nigeria. \\ 2Email:_hn.nzewi@unizik.edu.ng.Tel:+234806441850 \\ ${ }^{3}$ Email: ae.arachie@unizik.edu.ng.Tel:+2347031622889
}

ABSTRACT

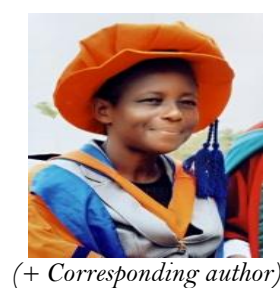

Article History

Received: 24 April 2020 Revised: 29 April 2020 Accepted: 5 May 2020 Published: 13 May 2020

\section{Keywords}

Accountability

Transparency

Nation building

Covid-19

Full disclosure

Citizens trust

Citizens buy-in.

JEL Classification:

E63; E63; M4; M21.

\begin{abstract}
The manifest mistrust between the government and the governed necessitated this study to examine the relationship between accountability and transparency on nationbuilding, using covid-19 experience as a yardstick. A survey research design was employed in the study. The population of the study consisted of 1174 employees of 5 ministries in Anambra State and the sample size was 298 using Taro Yamani formula. Questionnaire was used in collecting data. The instrument was subjected to face and content validity and was further tested for internal consistency using Cronbach Alpha and an average result obtained was 0.984. Data were analysed using Regression Analysis at $5 \%$ level of significance. Findings showed that there is a statistically significant relationship existing between full disclosure and citizens improved trust $(\mathrm{r}=$ $.984, \mathrm{R}^{2}=.899, \mathrm{~F}=1874.010, \mathrm{p}$-value $\left.<0.05\right)$, that there is a statistically significant relationship existing between impact reporting and citizens buy-in $\left(\mathrm{r}=.947, \mathrm{R}^{2}=.897\right.$, $\mathrm{F}=1842.355 \mathrm{p}$-value $<0.05$ ). Consequently, the study concluded that there would be no trust issues between both parties if full disclosure and impact reporting have been the hallmark of government in the past. Therefore, the study recommended among other things that Anambra State Anti-corruption Strategy (ANSACS) as a provider of holistic framework and foundation for a system-driven approach towards the fight against corruption, accountability and transparency needs to do all it can to encourage various government ministries and agency to engage more in full disclosure and impact reporting.
\end{abstract}

Contribution/Originality: This work contributes to existing body of knowledge in the area of accountability and transparency, but it is novel in using accountability and transparency to gauge citizens' response to government directives and policies to issues such as Covid-19 pandemic ravaging different economies of the world presently.

\section{INTRODUCTION}

It is evident that there is an existential mistrust between the government, its agencies and the citizenry in Africa, a situation that is visible in the current covid-19 pandemic ravaging the globe and Africa being part of a global village is not left out. Nigeria is the most populous country in the African continent, so, this study focused on Nigeria. The mistrust clearly elucidated between the government and its citizens has led many to even doubt the very existence of the virus and its concomitant potency in Nigeria. This is even more visible among the illiterate 
and the poor; those that are not privy to electricity, radio or television stations. They appear to be oblivious of the ravenous nature of the virus in other developed and developing climes of the world like in China (originating country), Italy, Spain, United States (US), France, Iran, United Kingdom (UK), Switzerland, Turkey, Germany and some South and North American countries. This doubt in the mind of Nigerians may not entirely be misplaced as the identity of the index case in Nigeria touted to be an Italian is as of today still unknown. The identity of those that have contracted the illness apart from highly placed politicians and governors in some states is still shrouded in secrecy. Those that have been discharged and the drugs used in treating them are still largely not made public. This has created an information lacuna, suspicion and trust issues among citizens. This suspicion and lack of trust appear to be a buildup of many years of poor governance, bad leadership and mismanagement. The manifestations are mostly explained by the persistence of inefficient and poor institutions, poor quality agencies, ineptitude civil service, disorganized markets, inefficient government-owned businesses, corruption due to lack of integrity occasioned by a complete absence of transparency and accountability that hinders nation-building (Akhigbe, 2017).

Leadership accountability and transparency are buzzwords in today's Nigeria society. The press is full of stories detailing the sordid affairs of leaders; organizations and agencies that have betrayed the confidence and trust of the public. Accountability and transparency are central to the art and science of governance of developed nations. The term describes a collective set of actions of leaders in all spheres of human endeavour, to account for actions taken, to be answerable to those that bestowed authority and to accept responsibility for the decisions and the outcomes of activities undertaken.

Moreso, transparency in government actions denotes increasing reliability and having a well-informed public (Agburuga, 2018; Doyle, 2005). It is, however, important to note that the concepts of accountability and transparency have a long tradition in both political and financial disciplines and they mean different things to different stakeholders. The central idea, however, remains that when decision-making powers are transferred from a principal (e.g the citizens) to an agent (e.g government), there must be a mechanism in place for holding the agent to account for their decisions and if necessary imposing sanctions, ultimately by removing the agent from power. In accounting, accountability refers to financial prudence and accounting with regulations and instruction (Lindberg, 2009). While transparency stands for responsive communication that incorporates various stakeholders in the communication process and justification to the citizen, of decisions taken by the government (Fairbanks, Plowman, \& Rawlins, 2007).

The imminent challenge for government in Nigeria is to make citizens trust government agencies, for there appears to be a nexus between citizens' satisfaction and the execution of government policies and programmes. This was captured by Doyle (2005) who opines that if the citizens are satisfied with government actions, they will also be satisfied with the government and its representatives. It is a known fact that public trust in government and political institutions has been declining in Nigeria over the years, behind which lies many reasons such as lack of citizens' satisfaction in government policies and diminished expectations. Other reasons are lack of transparency, accountability and poor government performance (Mahmood, 2016). Building trust in government is at the core of a nation's quest for peace and well-being. Therefore, public access to government information is a strategy to achieve transparency and holding government accountable.

Accountability involves stewardship and the obligation to accept responsibility. Leadership, accountability and transparency are detailed in the interplay between the governed and the government; people in power and how they answer for, or account for one action to some authority by reference to a defined benchmark. The reference benchmark of this study is nation-building which is understood as the practices and meaning that serve to create a shared cultural identity within the governed by a state and further aims at the unification of the people within the state so that it remains politically stable and viable in the long run (Beumer, 2019). Therefore, government policy progress depends on its ability to secure citizens buy-in of the policies and programmes of government. Nation- 
building is a process which lends to the formation of a country in which citizens feel a sufficient amount of commonality of interests, goals, and preferences (Alesing \& Reich, 2012, cited in Onuoha and Ugwueze (2014).

The nation, Nigeria, is particularly vulnerable to inefficiencies and losses from corruption because it involves the complex mix of actors with diverse responsibilities. Government actions continue to find themselves under the microscope of public scrutiny, leading to issues of governance, accountability, transparency and nation-building. There exist loss of trust which have insurmountable ramifications for a nation in attracting and establishing relationships with other sovereign nations and fostering legitimacy. Lack of accountability and transparency in leadership and governance leads to non-fulfilling of government obligations, profligate use of public finance, increased private interests, lawlessness and ineptitude; loss of will by public workers and loss of meritocracy and promotion of mediocrity in the public sphere and administration (Agburuga, 2018; Anne, Deirdre, Taryn, Jillian, \& Gilles, 2018). It becomes evident that the lower the trust, the harder it becomes to lead successfully; the lower the trust the harder for government policies to succeed and for public programmes to achieve the desired goals. It will also be less likely that the citizens will follow regulations without incentives or penalties with dampened trust. Therefore, a high level of accountability and transparency are critical for minimizing opportunities to fraud and leakages.

Robust public accountability and transparency are widely accepted to be indispensable for pursuing an egalitarian society. Hence, leadership accountability and transparency are measured in this study by full disclosure and Impact Reporting, respectively; while nation-building is captured by citizens improved trust and citizens buy-in which is visualized as a desired outcome.

This study is narrowed further down to Anambra State being one of the five States in the Southeastern geopolitical zones in Nigeria. The narrowing down of the study is occasioned by the fact that it is only the second state that has established an anti-corruption strategy known as the Anambra State Anti-corruption Strategy (ANSACS). This was done with the support of Rule of law and Anti-corruption Programme (ROLAC), a 4 year European Union (EU) funded programme that aims at enhancing good governance in Nigeria by strengthening the rule of law, curbing corruption and reducing impurity.

Anambra State with the support of ROLAC has developed the Anambra state Anti-corruption Strategy (ANSACS). The ANSACS provides a holistic framework and foundation for a system-driven approach towards the fight against corruption in Anambra State. It sets out standardized guidelines in five broad areas: Prevention, Public Engagement; Ethical Re-orientation, Enforcement and Sanctions; and Asset Recovery and Proceeds of crime. The strategy will guide the State government in deploying resources to its institutions to respond to corruption vulnerabilities and better address corrupt practices wherever they are found, thus enhancing accountability and transparency in Anambra State. (https://www.justice-security.ng). However, at present, it is uncertain if ANSACS has met its feats toward the fight against corruption in Anambra State by enhancing public accountability and transparency in the State which will lead to nation-building. This has created concern and the need to fill this gap has become necessary. This, therefore, has led to the need for undertaking a study on the enhancement of nationbuilding through accountability and transparency.

This study is even more crucial at this point to assess if the strategy on anti-corruption in the state through the encouragement of openness and accountability has helped in building trust among the players in the state polity. The State needs its citizens to play their role in following various health guidelines at preventing the spread of Covid-19 at this precarious time. Among such guidelines are the stay at home order by the state government, social distancing directive, closure of worship centres, schools and other social gatherings. The level of trust in government will come into play at this crucial period given that without trust existing between the governed and the government, these directives may not be followed without coercion. It could be viewed as another ploy for the people in government to corruptly enrich themselves at the detriment of the masses, people who may want to donate financially or materially may be deterred given the antecedent of government and its activities. In view of 
this, the primary objective of the study is to examine the relationship between accountability, transparency and nation-building. Specifically, the study seeks to:

a) Determine the relationship that exists between full disclosure and citizens improved trust in the state governance.

b) Ascertain the relationship that exists between impact reporting and citizens buy-in in the state governance.

\section{CONCEPTUAL AND THEORETICAL ISSUES}

\subsection{Accountability}

Leadership accountability describes the collective set of actions of leaders in all spheres of human endeavour, to account for actions taken, to be answerable to those that bestowed authority and to accept responsibility for the decisions and the outcomes of activities undertaken (Agburuga, 2018). It connotes a relationship in which we answer for or account for our actions to some authority. Therefore, accountability involves stewardship and the obligation to accept responsibility. Cordery, Slim, and ZijL (2017) aver that accountability and transparency are required from authorities, organizations and individuals, with a mandate to serve public interest. Accountability shines a light on democratic governance. It keeps the public informed and the government exposed, open to questioning. Intuitively, the government is accountable for its activities and way of governing. The term carries an implicit suggestion of being virtuous, a positive quality in government, organisations or management, thus leading to different aspects of accountability; fiscal honesty and avoidance of fraud, good governance, adherence to mission and demonstration of government effectiveness (Brody, 2001; Carlos, Quelhas, França, Meiriño, \& Zotes, 2014). It is understood from literature that accountability means that the government, individuals and organizations are responsible for acting according to certain standard and commitments; are answerable for their actions and will face consequences if standards are not met.

\subsection{Transparency}

Reliability of government institutions and individuals is tied to transparency. This is the position of Welch (2012) who posits that transparency is a means of increasing reliability. Transparency is a characteristic of government, companies, organizations and individuals that are open in the clear disclosure of information, rules, plans, processes and actions. Transparency in government actions and its decisions - making processes is the key to having a well-informed public. It can reduce vulnerability to corruption and unethical practices and improve trust in government institutions (Anne et al., 2018). It involves governments making information publicly available so that their actions and decisions are visible and understandable to the public so they can, therefore, be held to account. Transparency is both a means and an end in itself and is instrumental in enabling accountability and guides a wellgoverned democratic system. Government transparency can be defined by three elements, openness of information from the government; communication or knowledge sharing on the part of citizens, and accountability or justification, to the citizens of decisions taken by the government (Mexico Federal Institute for Public Information, 2008). Transparency informs stakeholders and thereby, facilitates their participation in policy process, which enables accountability (Anne et al., 2018).

\subsection{Full Disclosure}

This is an accounting principle that requires management, organization, government to report all relevant information about operations or activities to stakeholders. In other words, stakeholders require that government tell the public about material information about the economy that they can use to base their decisions on. The purpose of the full disclosure principle is to share relevant and material financial information with the outside world (https.//www.myaccounting.course.com). Full disclosure is the ethical standard that requires the complete exposure of every material fact that can make a financial statement unclear and misleading. 
There is a policy known as full disclosure policy which is a policy that requires the government of any form to fully disclose particular financial transactions of their activities to keep the governed informed of how budget is managed, disbursed and used (Benquet Full Disclosure Report, 2019). The presumption of disclosure also means that agencies should take affirmative steps to make information public (https://www.nfoic.org), thus releasing information before it is requested, thereby, creating an environment where information is released routinely through electronic means with the exception of information that the government is required to protect due to privacy risk. Full disclosure in this study connotes openness, the act of making something public.

\subsection{Impact Reporting}

It is a communication strategy that government, individuals, enterprises hope to inform and inspire their stakeholders, by communicating clearly the impact of their work thereby telling the society, people, workers and customers how they are fulfilling their purpose and achieving the change that they seek. Impact report means communicating the differences agencies made to the people they wish to help, or to the issue they wish to improve upon. It often takes the form of an annual report, but can also include reports to stakeholders, investors, supporters, funders and so on. Good impact reporting tells citizen of what government has achieved with public fund. Where it is applied properly, it helps the government develop and refine strategies to increase effectiveness. Impact reporting is directed towards key stakeholders like the citizens. A government that is able to establish and explain its impact will have a strong foundation both to communicating its work and also managing it to achieve the greatest possible impact (Building Public Trust, 2018).

\subsection{Citizens' Improved Trust (CIT)}

Trust means holding a positive perception about the actions of an individual or an organization. It is a subjective phenomenon reflected in the "eyes of the beholder" that matters especially to the extent that it shapes behaviour. CIT in government represents the confidence of citizens in the actions of a "government to do what is right and perceived fair". It depends on the congruence between citizens' preferences on the interpretation of what is right and fair and what is unfair, representing the perceived actual functioning of government (Mahmood, 2016; Walle. \& Bourkaert, 2003).

Citizens expect the government or public servants to serve the public interest with fairness and manage public resources in an efficient manner. Fair and reliable public services can act as a catalyst to improve citizens' trust and create a favourable environment for businesses to thrive. Without trust in governments, market and institutions, support for necessary reforms are difficult to mobilize particularly where short-term sacrifices are involved and long-term gains might be less tangible. The sharp decline in citizens' trust is an essential, yet often overlooked ingredient in successful policymaking. A decline in citizens' trust can lead to lower rates of compliance with rules and regulations (Government at a Glance, 2013; Morgeson, VanAmburg, \& Mithas, 2011).

\subsection{Citizens' Buy-in}

People are becoming more aware of their right and opportunities that lie ahead of them and are developing capabilities to make informed choices in all areas which influence them, including the sphere of governance. In this precarious era, the inhabitants of the knowledge societies will have all the more freedom, flexibility and opportunities to decide how they would like to be governed and by whom. The underlying truth will become selfevident that it is not the leader who govern people but it is the people who let leaders govern them (The World Bank, 1998).

Citizen' buy-in connotes the fact of agreeing with and accepting something that someone suggests. Effective leaders must understand how to communicate their vision and create buy-in of the citizens or the led. Thus, citizens' buy-in enhances collaboration and knowledge sharing within government and improves citizen services 
tailored to citizens' specific need which enthrones social cohesion. Social cohesion is the on-going process of developing a community of island values, shared challenges and equal opportunity within a nation based on a sense of trust, hope and reciprocity among citizens (Jeannotte et al., 2002). Citizens' buy-in is all about willingness to cooperate with the government on its policies and programmes.

\subsection{Coronavirus Disease 2019 (Covid-19)}

Covid-19 is a new strain in the family of coronavirus that has not been seen in the past. Buttressing this point, the United Nations Development Programme (2020) states that we are in uncharted territory with respect to the new coronavirus which was first identified in Wuhan, China. When the virus started, it was called '2019 novel coronavirus' or '2019-nCoV.' However, the virus has been renamed to (COVID-19). Each of the letters there stands for something. 'CO' stands for corona, 'VI' for virus, and 'D' for disease while the 19 is a short form the year 2019 when the virus was first recorded in Wuhan, China.

The COVID-19 virus has been linked to other families of viruses such as Severe Acute Respiratory Syndrome (SARS) and some types of common cold. Basically, the transmission mode of this virus is through direct contact with respiratory droplets of an infected person, generated through coughing and sneezing, and touching surfaces contaminated with the virus. Reports from various health sources such as World Health Organization (2020) and European Centre for Disease Prevention and Control (2020) are of the view that the virus can survive several hours on different surfaces and fabrics. But due to the novelty of the virus, the exact number of hours the virus can survive and remain contagious is still relatively unknown.

Several symptoms have been suggested for the virus. Among the common symptoms are fever, cough and shortness of breath. In more severe cases, an infection can cause pneumonia or breathing difficulties. United Nations Development Programme (2020) aver that symptoms differ in severity being asymptomatic (no symptom) to having fever, cough, sore throat, general weakness and fatigue and muscular pain and in the most severe cases, severe pneumonia, acute respiratory distress syndrome, sepsis and septic shock, all potentially leading to death. These symptoms are similar to symptoms of other viruses or diseases such as malaria, flu (influenza), and common cold, and as such, tests are required to confirm whether a symptom is that of Covid-19 or not.

Many preventive and precautionary measures have been suggested to curtail the spread of the virus. Among the measures suggested and supported by WHO are:

a) Frequent hand washing with soap and water or an alcohol-based hand rub (sanitizer).

b) Respiratory hygiene (covering of mouth and nose with flexed elbow or tissue when coughing or sneezing and disposing of used tissue immediately in a covered waste bin).

c) Avoid touching of mouth, nose or eyes with your hands.

d) Adhere to social distancing measures (avoid close contact with anyone who has cold or flu-like symptoms).

e) Alert the medical personnel if you start noticing unusual fever, cough or difficulty in breathing.

Hospitalisation rates for the virus are higher for those aged 60 years and above, and for those with other underlying health conditions such as hypertension, diabetes, cardiovascular disease, chronic respiratory disease and cancer. Men in these groups are also said to be at a slightly higher risk than females in the group (United Nations Development Programme, 2020; World Health Organization., 2020).

The vaccine for the virus is yet to be discovered as reports say it will take several months before any vaccine can be developed and pull through all the necessary trials and safety checks. ECDC (2020) opines that as this is a new virus, no vaccine is currently available. Although work on a vaccine has already started by several research groups and pharmaceutical companies worldwide, it may be months to more than a year before a vaccine will be tested and ready for use in humans. So, all we can do at this point is to observe all the safety measures and hope for scientists to come up with vaccines or for some kind of divine intervention to take place. 


\section{THEORETICAL FRAMEWORK}

The study is anchored on stakeholder management Theory. The Stakeholder Management Theory was credited to Freeman (1984) who popularized the stakeholder concept. The theory seeks to explain from the start on the stakeholder approach that organizations, business or government have identified groups with whom they had to deal with, hence emerged a management practice wherein planning process are becoming sensitive to the business environment and the need for good information. The theory demonstrates that changes in governance and business imply that the model of governance or organization as a mere resource - converter is no longer "valid" and suitable. Besides, accountability and transparency embrace the principle of public relations models and stakeholder management theory, both of which stand for responsible communication that incorporates various stakeholders in the communication process. This explains the relevance of the theory where the citizens, government, businesses and organizations are vital stakeholders in nation building. The practice of accountability through transparent revenue management by the government to all citizens constitute the hallmark of nation building.

\section{EMPIRICAL REVIEW}

Agburuga (2018) studied leadership accountability, budget and financial management performance and national security in Nigeria. The study adopted an ex-post-facto design where a twelve-year time-series data from 2005 to 2016 were used to elicit data from a secondary source, which involved the regression of national security indicators on leadership accountability and budget and financial management performance. The result confirmed that leadership accountability plays a role in enhancing national security in line with the theory of accountability.

Adagbabiri (2015) evaluated accountability and transparency: an ideal configuration for good governance. A literature review approach was adopted, the study concluded that strengthening government institutions, systems and structures are prerequisites for safeguarding public sector integrity.

Bauhr and Grimes (2017) undertook a study on transparency to curb corruption. The study adopted a correlation research design. Data were collected through a global survey by public administration by a means of the questionnaire. Finding indicated that the level of democracy is generally insignificant when accounting for the effect of transparency.

Olaopa (2016) investigated "good governance: accountability and transparency for sustainable development in Africa. A literature review design was adopted. The findings showed that there is a great need for government institutions' renewal and administrative reforms for good governance in Africa.

\section{METHODOLOGY}

The study adopted a survey research design because data were sought through questionnaire and from sampled respondents. Out of the 19 existing ministries in Anambra State, 5 ministries (Ministry of Industry, Trade and Commerce, Ministry of Economic Planning, Budget and Development partners, Ministry of Tertiary Education, Ministry of Finance and Ministry of Information) with a combined population of 1174 were selected judgmentally based on their critical financial relationship with perceived activities of stakeholders when transparency and accountability are violated in Nigerian and Anambra State polity. Taro Yamane formula was used in determining the sample size of 298. Questionnaire was used in collecting data from the respondents for the analysis. It was structured in a five-point Likert scaled format to aid in transforming the qualitative response into quantitative data so that an empirical result can be drawn from it. A total of 298 copies of questionnaire were distributed to the focused ministries/institutions, 213 copies were retrieved and used for the analysis. The instrument was subjected to face and content validity. The study instrument was further tested for internal consistency using Cronbach Alpha and the average results obtained was 0.984 , this means that the instrument was reliable. Data were analysed using Regression Analysis at 0.05 level of significance signifying a $95 \%$ level of confidence. 
5.1. Data Analysis and Discussion

5.1.1. Test of Hypothesis

$H_{A 1}$ : There is a significant relationship existing between full disclosure and citizens improved trust.

Model Summary

Table-1. Summary of regression one.

\begin{tabular}{l|c|c|c|c}
\hline Model & $\mathbf{R}$ & R Square & Adjusted R Square & Std. Error of the Estimate \\
\hline 1 & $.948^{\text {a }}$ & .899 & .898 & 1.355 \\
\hline Note: a. Predictors: (Constant), FULLDISC \\
Full disc: Full Disclosure. \\
Source: Field survey, 2020.
\end{tabular}

Table 1 shows the summary of the model for hypothesis one, it reveals that the correlation coefficient represented by $\mathrm{R}$ is .984 meaning that a positive relationship exists between full disclosure and citizens improved trust. The coefficient of determination represented by $\mathrm{R}$ Square $\left(\mathrm{R}^{2}\right)$ is .899 meaning that a $90 \%$ change in the dependent variable (citizens improved trust) is accounted for by changes in the independent variable (full disclosure).

ANOVA $^{a}$

Table-2. Test of hypothesis one.

\begin{tabular}{|c|c|c|c|c|c|c|}
\hline & Model & Sum of Squares & df & Mean Square & $\mathbf{F}$ & Sig. \\
\hline \multirow{3}{*}{1} & Regression & 3443.127 & 1 & 3443.127 & 1874.010 & $.000^{b}$ \\
\hline & Residual & 387.671 & 211 & 1.837 & & \\
\hline & Total & 3830.798 & 212 & & & \\
\hline
\end{tabular}

Table 2 reveals the result of the test of hypothesis one represented an ANOVA table. From the table, the $\mathrm{F}$ Statistics which represents the model fitness is 1874.010 while the p-value (sig) is .ooo. Because the p-value is less than $5 \%$ level of significance ( $\mathrm{p}$-value $<0.05$ ), the alternate hypothesis stands and it, therefore, means that there is a statistically significant relationship existing between full disclosure and citizens' improved trust. This goes to show that the more the government and its agencies and ministries engage in prompt and complete dissemination of information, the more the citizens will trust the government and vice versa.

$H_{A 2:}$ There is a significant relationship existing between impact reporting and citizens buy-in.

Model Summary

Table-3. Summary of regression two.

\begin{tabular}{|c|c|c|c|c|}
\hline Model & $\mathbf{R}$ & R Square & Adjusted R Square & Std. Error of the Estimate \\
\hline 1 & $.947^{\mathrm{a}}$ & .897 & .897 & 1.327 \\
\hline
\end{tabular}

Table 3 indicates the model summary for hypothesis two. It is shown in the Table that R which represents the correlation coefficient is .947 indicating that a positive relationship exists between impact reporting and citizens buy-in. The $\mathrm{R}^{2}$ is shown in the Table is .897 indicating that a $90 \%$ change in the dependent variable (citizens buyin) is explained by changes in the independent variable (impact reporting). 
Table-4. Test of hypothesis two

\begin{tabular}{|c|c|c|c|c|c|c|}
\hline \multicolumn{2}{|c|}{ Model } & Sum of Squares & df & Mean Square & $\mathbf{F}$ & Sig. \\
\hline \multirow{3}{*}{1} & Regression & 3242.251 & 1 & 3242.251 & 1842.355 & $.000^{b}$ \\
\hline & Residual & 371.326 & 211 & 1.760 & & \\
\hline & Total & 3613.577 & 212 & & & \\
\hline
\end{tabular}

Table 4 is the ANOVA Table for the test of hypothesis two. It is seen in the Table that the F Statistics is 1842.355 while the p-value (sig) is .000. The Table shows that the p-value is less than $5 \%$ level of significance (pvalue $<0.05)$, the alternate hypothesis is accepted and it is concluded that there is a significant relationship existing between impact reporting and citizens buy-in. The practical implication of this result is that when the government and its agencies and ministries do more of impact reporting, citizens will buy-in more to the programmes and policies as no one wants to be left in the dark as to what is happening in government. Therefore, the more impact reporting is undertaken by the government, the more citizens will buy-into the programmes.

\section{DISCUSSION OF FINDINGS}

The discussion is done according to the research objectives as follows:

The result of the first hypothesis revealed that there is a very strong positive relationship between full disclosure and citizens' improved trust. This implies that leadership accountability and transparency can be possible in Anambra State, when ANSACS enforces full disclosure of actions and decisions taken and communicates the same to the stakeholders which facilitate public dialogue, and solicits feedback, questions and suggestions for how to improve government and at the end, the level of trust in government by the citizens will improve. The result findings are consistent with Olaopa (2016) who revealed that information and communication are integral to improving access to public services and by extension elicit public goodwill and trust.

The result of the second objective revealed a positive relationship between impact reporting and citizens buyin. Government improved engagement in furnishing the citizens with the outcomes of various programmes, policies and actions of government gives the people a sense of belonging and ownership and therefore would key-in and support such programmes and policies. The result supports the work of Adagbabiri (2015) which showed that leadership information to stakeholders allows the public and government to learn from each other.

\section{CONCLUSION}

The doubts on the mind of many citizens of the country and indeed citizens of Anambra State on the veracity of the existence of covid-19 in the country and in the state would not have been the case if the government has been engaging in prompt and complete disclosure of issues the citizens are supposed to know. There would be no issue of doubt if impact reporting has been the hallmark of government in Africa in general, Nigeria and Anambra state in particular before now. As a result of the absence of these accountability and transparency measures, a trust issue has been created between the governed and the government. This is so because, from the findings of the study, it was seen that citizens will trust government more and buy into their policies and programmes with improved disclosure and impact reporting.

\section{RECOMMENDATIONS}

In view of the above findings, the study recommended that:

1. ANSACS as a provider of holistic framework and foundation for a system-driven approach towards the fight against corruption and improved accountability and transparency needs to do all it can by punishing or incentivizing the agencies and ministries of government to encourage them to engage the citizens more 
in form of full disclosure of actions and policies and impact reporting of various government activities and intervention programmes.

2. ANSACS through their action plan needs to enforce sanctions against any government agencies/ministries that do not inform and inspire stakeholders on purpose fulfilment base on time limits to deter further occurrences.

Funding: This study received no specific financial support.

Competing Interests: The authors declare that they have no competing interests.

Acknowledgement: All authors contributed equally to the conception and design of the study.

\section{REFERENCES}

Adagbabiri, M. (2015). Accountability and transparency: An ideal configuration for good governance. Developing Country Studies, $5(21), 1-5$.

Agburuga, U. T. (2018). Leadership accountability, budget and financial management performance and national security. Paper presented at the 12th Annual National Conference of the Academy of Management, Nigeria.

Akhigbe, O. J. (2017). Governance, leadership and management practices in nigeria public sector: Ventilating a recessed and suffocating economy. Paper presented at the A Conference Paper Submitted to the Department of Business Administration 2017 International Conference titled; Managing A Recessed Economy Options for Nigeria.

Anne, P., Deirdre, Taryn, V., Jillian, C., \& Gilles, F. (2018). Transparency and accountability in pharmaceutical systems: Increasing transparency and accountability in national pharmaceutical systems. Publication Bulletin of the World Health Organization, Type: Policy \& Practice, 1-2 1: Article ID: BLT. 17. 206516.

Bauhr, M., \& Grimes, M. (2017). Transparency to curb corruption? Concepts, measures and empirical merit. Crime, Law and Social Change, 68(4), 431-458.Available at: https://doi.org/10.1007/s10611-017-9695-1.

Benquet Full Disclosure Report. (2019). Philipine Transparency Seal.

Beumer, K. (2019). Nation-building and the governance of emerging technologies: The case of nanotechnology in India. NanoEthics, 13(1), 5-19.Available at: https://doi.org/10.1007/s11569-018-0327-8.

Brody, E. (2001). Accountability and public trust in Doyle, L. M. (2005). Nonprofit board accountability: A literature review and critique. SPNA, 1(1), 27-37.

Building Public Trust. (2018). Reporting with purpose and impact. pwc.co.uk. Retrieved from: http:www.thinknpc.org in 2019.

Carlos, S. D. S., Quelhas, O. L. G., França, S. L. B., Meiriño, M. J., \& Zotes, L. P. (2014). Transparency in government institutions: A literature review. Brazilian Journal of Operations \& Production Management, 10(2), 33-43.

Cordery, J., Slim, D., \& ZijL, T. (2017). Differentiated regulation: the case of charities. Accounting and Finance, 57(1).

Doyle, L. M. (2005). Nonprofit board accountability: A literature review and critique. SPNA Reviewe, 1(1), 27-37.

European Centre for Disease Prevention and Control. (2020). Retrieved from: https://www.ecdc.europa.eu/en/covid19/questions-answers. [Assessed 15-04-202].

Fairbanks, J., Plowman, K. D., \& Rawlins, B. L. (2007). Transparency in government communication. Journal of Public Affairs: An International Journal, 7(1), 23-37.

Freeman, R. E. (1984). Strategic management: A stakeholder approach. New-York: Boston Pitman.

Government at a Glance. (2013). Trust in government policy effectiveness and the governance agenda. OECD. Retrieved from: https:/ / www.oecd-ilibrary.org/docserver/gov_glance-2013-6en.pdf? expires=1588624999\&id=id\&accname=guest\&checksum=43B2BEBD58496BAFCE64772E 1 AE66940.

Jeannotte, M. S., Stanley, D., Pendakur, R., Aziewood, A., Jannieson, B., \& Willian, M. (2002). Buying -in or Dropping out: The public policy implications of social cohesion research. Strategic Research Analysis (SRA). SRA-631-e, 1-38.

Lindberg, S. I. (2009). Accountability: The core concepts and its subtypes. The APPP Discussion Paper, Working Paper No. 1. 
Mahmood, M. (2016). Enhancing citizens' trust and confidence in government through digital transformation. International Journal of Electronic Government Research (IJEGR), 12(1), 99-110.Available at: https://doi.org/10.4018/ijegr.2016010105.

Mexico Federal Institute for Public Information. (2008). IFAL criteria and resolutions.

Morgeson, I. F. V., VanAmburg, D., \& Mithas, S. (2011). Misplaced trust? Exploring the structure of the e-government-citizen trust relationship. Journal of Public Administration Research and Theory, 21(2), 257-283.Available at: https://doi.org/10.1093/jopart/muq006.

Olaopa, T. (2016). Good governance: Accountability and transparency for sustainable development. Paper presented at the 3rd International Conference African Development Issues (CU-ICAD 1, 2016).

Onuoha, J. I., \& Ugwueze, M. I. (2014). Political scientist and nation-building. International Journal of Social Science and Humanities Research, 2(4), 35-48.

The World Bank. (1998). New economy sector study of electronic government and governance: Lesson for Argentina.

United Nations Development Programme. (2020). COVID-19 pandemic: Humanity needs leadership and solidarity to defeat the coronavirus. Retreived from: https:// www.undp.org/content/undp/en/home/coronavirus.html.

Walle., V. d., \& Bourkaert, G. (2003). Public service performance and trust in government: The problem of causality. International Journal of Public Administration, 26(8-9), 891-913.Available at: 10.1081/PAD-120019352.

Welch, E. W. (2012). The relationship between transparent and participative government: A study of local governments in the United States. International Review of Administrative Sciences, 78(1), 93-115.Available at: https://doi.org/10.1177/0020852312437982.

World Health Organization. (2020). Emerging respiratory viruses, including COVID-19: Methods for detection, prevention, response and control. Retrieved from: https://openwho.org/courses/introduction-to-ncov. [Assessed 15-04-202].

World Health Organization. (2020). Global research on coronavirus disease (COVID-19). Rtrieved from: https://www.who.int/emergencies/diseases/novel-coronavirus-2019/global-research-on-novel-coronavirus-2019ncov. [Assessed 15-04-202]. 